\title{
Yeats' Views of Life and the Possibility of the Coming Back of the Soul after Death
}

\author{
Dr. Amal Riyadh Kitishat ${ }^{1 *}$, Khawla AL- Omar ${ }^{2}$ \\ 1. Al Balqa Applied University- Ajloun University College, Dept. of English Language. \\ P.O box (1) Postal code 26816, Ajloun, Jordan \\ 2. Al Balqa Applied University- Ajloun University College, Dept. of English Language. \\ P.O box (1) Postal code 26816, Ajloun, Jordan \\ * E-mail of the corresponding author: dr.amal.kitishat@bau.edu.jo
}

\begin{abstract}
This study aims at shedding light on Yeats as a philosopher, especially his views of life and the possibility of the coming back of the soul after death. The study aims at investigating Yeats' philosophical attitudes as presented in Purgatory. Though the title denotes Christian implications, the study aims to prove that it is far away from Christianity. Rather, as the study argues, it is a summary of Yeats' philosophic beliefs; especially his views of life and death. In Purgatory, Yeats interlinked between philosophy and literature magnificently. He employed modernist theatrical techniques by using light and sound techniques supported by symbols and imagery to express his themes. Yeats focused on the concept of purgation as presented in Purgatory The study concludes that Yeats' Purgatory is a prediction of a degeneration in humanity in general, and of Irish society, unless people "purify" their race by choosing to be away from any form of corruption. In the play, the father killed his son because he is afraid that he would repeat the same crime that his father had done many years ago. This crime is discussed metaphorically it stands for many political meanings, Yeats warned people that if purgation is not performed wisely, it will lead to a failure of civilization and the rise of a state of anarchy. Therefore, Yeats' Purgatory, as the study proved, is a metaphoric portrayal of the political, cultural and historical milieu of Ireland presented in a philosophical context.
\end{abstract}

Key terms: Irish drama; Irish Theatre; Yeats' occult and philosophy; New/Historicism; Purgatory.

DOI: $10.7176 / \mathrm{JEP} / 11-5-15$

Publication date: February 29th 2020

\section{Introduction}

Purgatory is considered among Yeats' best plays, critics highlight its value since it is attributed as "one of Yeats's most accessible plays, as well as... of the best" (Knowland, 227). This play enables us to conceive Yeats as a philosopher who asserted the spirituality of the Irish identity as a major pillar by which the Irish identity should be marked. A. Norman Jeffares, in "Yeats as an Example?" refers the play's importance to the fact that it presents Yeats' "exemplary moments", and at the same time it exhibits a professional literary excellence hat is susceptible to the twinge and bathos of human life $(1980,57)$. Notably, Yeats draws on Irish "rituals" and rural customs, but he modernized them by his dramatic presentation and treatment which mixed Naturalistic and Symbolist attitudes where alienation was altered because of spiritual loss (Mc Ateer, 5).

Perhaps it is important in this context to discuss the source of this play which was a dream that Yeats had. I, Yeats wrote that he had a brief play in his mind, that consists of a of tragic passion.This short play is about a dream that he was so afraid of. Yet he aims in this play to embody this nightmarish dream.

\section{METHODS}

The study adopts post-colonial criticism as method of analyzing Purgatory, as Yeats metaphorically discussed his own philosophy in light of post -colonial Ireland and the radical changes of the social classes. Apparently, Yeats' purgatory manifests a dramatization of this political reality of Ireland form a postcolonial vision for the 
Anglo-Irish Ascendency their marginalization revealed itself in many forms in which the economic and the political and spiritual factors are interconnected (Foser,88). The study tackles this issue argufying that purgatory is in light of postcolonial reality related to a period after independence Ireland and the results for all Irish people who had apprehended authority and supremacy before 1922 (Grene, 2000, 170).

\section{RESULTS AND DISCUSSION}

To have a better understanding of Yeats' philosophy as shown in Purgatory, the study aims to discuss Yeats' interests in the occult since it is relevant to the gist of the play's philosophical meaning. Yeats' interest in occult reveals his philosophical orientation. Yeats was in a continuous endeavor to understand life and metaphysical issues such as life after death, and the possibility of having a way of communication with the dead. This can be seen clearly in his interest in automatic writing. An experimental attempt that Yeats had with his wife George to reach any possible way of communication with the spirits of the dead. These experimentations made his plays difficult for the ordinary Irish man. Notably, the audience failed to transcend the metaphoric representation to get the hidden meaning and the philosophic vision behind it. This is because, as Richard Taylor argues "the audiences of Yeats day were not prepared for the level of innovations that Yeats introduced to the Irish drama, Taylor argues that Yeats' plays were "a head of its time" (Mc Ateer, 3).

Also, it is these philosophical orientations of Yeats that hard-pressed him to present his vision in a literary form. For instance; Bernard O' Dengue argues that Yeats plays were full of uncertainty. In fact, Yeats was constantly experimenting all over his profession to introduce a new dramaturgy, adopting himself to the up-dates in the Irish habitat. (Mc Ateer,4).In this light, Purgatory is considered as a condemnation of Yeats' present-day European culture since the end of 18880s (Mc Ateer,9).

Moreover, the play has religious and philosophic significance. The plot of the play presents a metaphoric meaning deeper than the ordinary audience could perceive. Thus, when Purgatory was first staged, it had "a considerable number of hecklers, especially the common Irish people who were affronted by what appeared to be to a disrespect for religion. Purgatory as a play embodies Yeats' apprehension of the position of the Ascendancy after the First World War. Yeats believed that "the social reality of the Ascendency, its Church and its houses", were in danger from the major Catholic middle class (Foster, 88). In fact, Yeats was one of those Anglo-Irish Protestant Ascendancy who felt that they were marginalized in the Irish society:

Irish Protestants who were marginalized because they lived in England "but regretting Ireland, stemming from colourations, whose occult preoccupations surely mirror a sense of displacement, a loss of social and psychological integration" (Foster, 90-91). To clarify this idea, I would like to refer to Yeats' philosophic themes in and Vision in the Later Plays. Yeats believed in the purgatory of the dead people, but its period will differ according to the sins committed during one's life. In the play, the purgatory is not a religious one; however, the 4 study argues it is a purgatory of the dead mother's soul for her wrong marriage which led to a "degeneration" in Yeats' point of view. This belief is also held by Donald Childs in Modernism and Eugenics: Woolf, Eliot, Yeats and the Culture of Degeneration, Childs takes the play as an allegory of how the "impulsive marriage" leads to "a degeneration" because of the conflict between Irish classes: Ascendancy and middle class (182). On the other hand, others have regarded the play as a metaphor of "the fallen state which according to Yeats' vision had become ruined because of its involvement with lower classes, and so it foreshadows the absurd "purgation" of European civilization after the second World War (Vender, 195).

Also, Donald Torchiana provides an extra additional point of access in W.B. Yeats and Georgian Ireland, he states that "[e]eighteenth- century excellence fallen on evil days. A ruined house, ruined family and ruined tree suggest individual familial and national failures". (363). Therefore, if we take these explanations of the theme of the play, the play can be metaphorically seen as an answer to the question that is posed, about what ways the Ascendancy functioned they were just a Protestant minority and the power the hands of major Catholic Irish (Grene, 2000, 170).

Referring to the play's opening, Yeats exemplifies this metaphoric reading, this analogy can be best seen in the image of "the house" which is a recurrent image used by the Anglo-Irish writer as symbols or a personification. 
From the inside, a prevailing sense of an intimidation dominated the setting (Foster, 87). The image of the old house is also recurrent in Yeats' writings, which foreshadow lack of confidence about whether they will last. This sense dominates Yeasts' writings (Foster, 95). This meaning is expressed clearly in Purgatory, Yeats declares that "To kill a house,/Where great men grew up, married, died I here declare a capital offence"(Larrissy, Purgatory 1997, 336).

Moreover, there is another symbolic meaning in addition to the previous one, the reference to "that house", the study argues, stands for Ireland. The gloomy atmosphere dominates the setting whose "jocks and stories" are not heard any more for they had "gone to patch a pig-sty.". This "pig-sty" is a metaphoric implication of colonial Ireland and the English colonization of the "house". This meaning, in my opinion, is reasserted when the old man attracts our attention to the "shadow of a cloud upon the house / And that's symbolical; study that tree, / what is it like?" (Purgatory, 334). The connotation of the word "cloud" is without doubt a negative one since it is always linked with trouble and disorder. An atmosphere of rottenness controls the whole setting, the Old Man points out to this fact as follows:

I saw it fifty years ago

Before the thunderbolt had driven it,

Green leaves, ripe leaves, leaves thick as butter,

Fat greasy life. Stand there and look;

Because there is somebody in that house.(Yeats, Purgatory, 334)

In the previous lines, one can understand, the researcher argues, why the tree was described at the beginning of the play as "bare", Yeats justified this bareness to its being struck by a "thunderbolt" fifty years ago. Apparently, it is urgent in this context to emphasize the historic background of this play since as Knowland states this awareness of the history behind the contemporary situation in Ireland will, of course "deepen and extend appreciation, but even without that the play stands on its own feet" (227). Besides, Knowland supports Torchiana historic elucidation of the play. He states that it is related to:

the original scenario of the play, which has the Old Man begotten 63 years before the time of the play, 1938which puts the riving of the symbolic tree just before Parnell was rejected in $1889 \ldots$ the Old Man's mother represents the.... Period... which established a Protestant Ascendancy upon Catholic Ireland, She betrays the values of her class origins by coupling with a groom and so initiates the process of degeneration. Historically, Ireland moves from the Protestant Ascendancy to the Garrison to democratic bonhomie. (Knowland, 229)

Therefore, the main theme of the play is directly related to the history of post-colonial Ireland, Purgatory uncovered Yeats' awareness of the serious changes that took place in the Irish social classes .As Holdeman states Yeats' plays embodies the political, religious and social changes that dominated Europe after the end of WWII. Ascendency There is a focus on the chaos and confusion created by the Great Depression, this situation converted Yeats as well as other Irish people to adopt new philosophies, since they believed that liberal capitalism and democracy had failed.

When it comes to the concept of purgation from Yeats' perspective, Yeats expressed argues that in order for Irish nation to develop, Irish people should empower the "well-bred elites" in one hand, and limit the reproductive rights of the illiterate classes (quoted by Holdeman,103). However, according to Mac Liammor and Evan Boland, the Irish audience had "rioted" against Yeats' plays, because Yeats was suspected by many Irish people who considered that Purgatory is a "“[h]heresy', even more, was considered in some areas of Ireland as "“pose and tomfoolery, ... 'Had his tongue in his cheek when he wrote that nonsense?' is a phrase which sums up point of view as well as another (Mac Liammor and Evan Boland,1998,127). Probably, the reaction of the people toward the play was so violent because they the "house" which was mentioned in the play reminded the Irish audience of Tyrone House.

The study contends that Yeats draws on this story which was known among the Galway people when he wrote his play. In other words, Yeats "took a garbled version of the story" for writing Purgatory in which he described the decline of the ascendency. (Foster,89-90). It is in this sense that Denis Donoghue discussed these changes in "Yeats' Ancestral Houses and Anglo-Ireland" (1986); he refers Yeats' political pessimism to his "feeling" that is 
"turned upon a social class that failed to defend itself entered into debauched relation with the worst of drunkards, gambles lechers". (59). Obviously, the Irish audience who watched the play in 1938 must have in mind the fact of the fall of the Protestant Ascendancy and the rise of the middle Catholic class. So, this historical awareness reveals the "political intentions" in Ireland during that time, and so the play is a "contrasting dramatization of a post-colonial situation, as well as 'symptomatic of the off-center position' which Yeats shared in relation to Irish drama" (Grene, 2000, 171).

Furthermore, taking this play from a cultural critical perspective, Purgatory can be regarded as a protest the material dominance of the modern European societies. Regarding this point, Smyth, in Decolonization and Criticism: The Construction of Irish Literature, states that it is the "anti-materialist strain that constitutes Yeats's most important contribution to contemporary Irish cultural politics" (74). Realizing the increasing influence of "commercialism and materialism", Yeats expressed his dissatisfaction of the decline of spirituality. He himself declared that he himself blamed the educated elite in the Irish society because they were responsible for the failure of the spiritual and intellectual values which was defeated in front of the prevailing commercialism and materialism (qtd in Culling ford, 1984, 24). Yeats not only believed in the spiritual aspect of man as "an outbreak of 'race pride', but also as "an affirmation of spiritual traditions "against the creeping uniformity of modern materialistic civilization", and defense of the people against the middle class values (Culling ford, 1984, 11). Consequently, the form of Yeats' plays in general, and Purgatory in particular the is important because they are seen as an outcropping of the association of the secular with the spiritual world (Taylor , 1984, 5).Therefore, Yeats' purgatory could be taken as an example of Yeats' perspective of the relationship between the "playwright and philosopher". (Ure, 112). Though the play is regarded to be complex, such literature is highly estimated; for example, Kiberd, in Inventing Ireland, states that its "most striking" value is "remarkable without being lucid", for Kiberd, the great literature has the facility to commune before it is fully unspoken. (1996, 312-13). Also, Maxwell elevates the play's value to the rank of an "epic" he asserts:

It [Purgatory] is a miniature form, the short playing time the same as its 'real' time, and it is asked to accommodate the action of an epic stretches of Irish legends, abstruse brooding on fate, heroic virtue, transaction between life and after life. The necessary compression is rich not in radiant ambiguities but in sibylline obscurity. $(1988,24)$

In fact, the former critical opinion is in accord with Eliot's who substantially appreciated this play because of the astonishing dramatic talent with which Yeats has put a great deal of achievements in a one-act play with a masterly account of the old man's emotion. The importance of the play is due not only to its grandeur epic style, but also highlights its cultural value. Thus, the play is directly related to the Irish cultural reality and so it offers a high degree of authenticity. Apparently, this reality challenged him both in the personal and literary levels. There is a plain "paradox" between "the liberal decolonization" on the one hand and the authenticity of expressing the Irish national.(Smyth ,75)

Furthermore, Purgatory sheds light on the relationship between old values of Irish culture in general and the fact that "Anglo-Ireland" is "emerging" into a modern Irish nation (Smyth, 73).In other words, in this play, Yeats expressed some reservations against the changes that the whole Irish society witnessed especially the middle class .No doubt, Yeats expressed his refusal of common sense and attacked the increase of middle-class material values and the loss of the spirituality of the Irish culture.

Referring to the text itself, this meaning is implied in the old man's dialogue with the boy:

Re-live their transgressions and that not once

But many times; they know at last

The consequence of those transgressions

Whether upon others or upon themselves;

Upon others, others may bring help,

For when the consequence is at an end

The dream must end; upon themselves 
And in the mercy of God. (Yeats, Purgatory, lines34- 41)

In other words, Yeats' Purgatory is an embedded warning for the Irish audience of neglecting any cultural role of the Anglo-Irish class or the Ascendancy role in the Irish culture, Donoghue refers to it as Yeats' "hysterical" dream. He writes:

This is the hysterical version of Yeats' dream of kinship between peasant and nobleman, predicted upon the great estates in rural Ireland. It is a dreadful mood to have come to, but it is also touching in its appalling way... Yeats steadies himself to say that while "the Irish masses", as he calls them meaning the Catholic middle -and- lowermiddle class, "are vague and excitable because they have not yet been molded and cast, we have as good blood as there is in Europe. (60-61)

Applying the cultural perspective on the play, we can see the old man's conflict in this Anglo-Irish dilemma where the old man is caught in "a trap" between "peasant cabin and aristocratic Big house". He is a "mixture of half-educated peasant and landowner, lost representative of a doomed tradition." (Knowland, 230). Clearly enough, we can conclude that the personal dilemma of the Old Man is in his awareness of the contradictory elements in his own character. T.S. Eliot also supports this conjecture since he sees the suffering of the old man in a universal dimension. Eliot believes that Yeats, by introducing the Old Man's character he, "can speak for everyman, or for men very different from himself with every man or other men" (59).

Thus, we can argue that by introducing this character, Yeats attempted to convey the hybrid identity as a problem for men who are like him. The whole play is presented through the agony of the old man and his son, the core of the play can't be understood without the interaction between the past and the present.

In "Anglo-Irish Attitudes" Declan Kiberd discusses the hybridity as a major reason for the Old Man's dilemma, he states that Yeasts' resolution to this predicament, of " Anglo-Irish antithesis" , was to assemble a native Irish spectators and create in Dublin a theatre that could express the true spirit of Ireland. $(1984,13)$

Therefore, Yeats' tension is apparently expressed in this play he attempts to find an outlet from this tackling issue. Edward Said asserts that both obsessed Yeats and authorized him as a writer was able to cause an impassioned pressure. $(1992,80)$. Said argues that when the colonial situations are considered, the result will be 'insight and experience'. Said related Yeats' importance to his ability to create metaphors and symbols depicting the material colonial brutality. So, it is necessary to study the symbols that Yeats presented in this play to see how far this post "colonial turbulence" is presented. Regarding this point, Helen Burke, in "Acting in the periphery: the Irish theatre" comments on the relationship between colonialism and modernity; she states:

Purgatory clearly portrayed the post-colonial Ireland and the confusion and disorder that dominated the country; Yeats' Anglo-Irish origins raised many suspicions round him. In Purgatory, Yeats embodied both his confusion and fears of the Ascendancy's losing their strength and authority. Regarding this point, Marjorie Howes discusses Yeats' Anglo-Irish nationality as a crisis in post-colonial Ireland. The current study argues that Yeats's hybrid origins were also the sources of Anglo-Irish nationality devastating, and this led to a sense of weakness and irretrievable fragmentations. One can say that his vision aims to expose the lack of spirituality and the creeping influence of materialism over the post war Ireland.

Consequently, the Old Man is portrayed in conflict between "the consciousness of his aristocratic past and the degeneracy of his own father." (Knowland, 229) The father's burning of "his Protestant past" and so Ireland's rejection of Parnell, is a rejection of "the aristocratic future" (Knowland, 229). However, the Boy's character can also be seen in this light for he "embodies a progressive decline, not only the decadence of the individual soul, the drying of the marrow from the bones, but the desiccations of the sap in the life of the nation, which, stands like a tree withered and bare in the cold light of the future" (Knowland, 231).

Pursuing this supposed analogy, it is essential to explain the cultural and historical reading of Purgatory. No doubt, Yeats' use of symbols and metaphors is recurrent in this play. Indeed, from the opening until the play's end, Yeats presented symbols that hint deeper cultural meanings. For instance, Mc Donald supplements this fact, he states that the understated ways the metaphor plays a great role in Yeats' handling of actual Irish reality represented in ancient homes and towers (13). Besides, the most important symbol in this play is the ruined "big house". Thus, it could be interpreted the big house can stand as a symbol of the fallen class of "Ascendancy" in Ireland. In fact, Purgatory presents Yeats' "disgust with an Ascendancy Ireland which lost courage and corrupted 
its blood..." (Donoghue, 59). This fact is expressed in the play in the Old Man's words describing his old ruined house:

Great people lived and died in this house,

Magistrates, colonels, members of Parliament,

Captains and governors and long ago.

Men that had fought at Aughrimand Boyne.

Some that had gone on Government work

To London or to India came home to die,

Or come from London every spring

To look at the May-blossom in the park. (Yeats, Purgatory, 60-61)

The previous extract indicates Yeats' appreciation of a past and tradition as represented in the house which was used to gather Irish people from different ranks and positions. This house, which is no longer in its place for it is ruined and dwelt only by ghosts. The symbolic implications are so apparent to the extent that we feel Yeats' "self-condemnation" (Knowland, 231) as expressed by the old man himself:

But he killed the house, to kill a house

Where great men grew up, married, died,

I here declare a capital offence. (Yeats, Purgatory, 336)

From a historic context, the image of the ruined house has a symbolic implication of the historical disorder of Ireland in 1914-23. The 1938 audience who watched the image of the ruined house would remember the burning of "many great houses, even if not consciously focused on one house or another, the image would have conjured up generically the landscape reminders of the Troubles" (Grene, 2000, 173). Thus, the ruined house "stands for the lost class of the landed Anglo-Irish" (Grene, 2000, 171). Knowland also verifies the interpretation of the house's landscape that is "disfigured with the insignia of its past-the roofless shells of abandoned buildings, whether these are the product of rural decay hastened by the famine years, or of the kind of violence that erupted during the civil war years of 1922-3 when so many big houses were burned down"(229).

Another symbol that is recurrent in the play is the horse-breeding imagery. The Old Man attracts his son's attention to the sound of hoof-beats:

Old Man: Listen to the hoof beats! Listen, Listen!

Boy: I cannot hear a sound

Old Man: Beat! Beat. (Yeats, Purgatory, 337)

The Boy cannot hear the sound simply because it is in his father's consciousness. The significance of the horse's hoof beats could have a deep meaning taking into considerations that his father was a groom in a training stable. The Old Man states:

My mother that was your grand dam owned it,

This scenery and this countryside,

Kennel and stable, horse and hound

She had a horse at the curragh, and there met

My father, a groom in a training stable;

Looked at him and married him.

Her mother never spoke to her again,

And she did right. (Yeats, Purgatory,47-54)

The horse-breeding imagery is "equivalent of the Derby Winner". Being from a noble class of "an ancient 
household", his mother's marriage of a groom in a training stable" picks badly". It is as her son called a "capital offence" (Purgatory, 336). Taking the "farm -yard" symbols from a eugenically perspective, "her groom is her 'horse at the curragh' whose 'hoof-beats' torment his son... this woman makes a dysgenic choice that causes the blood line for which she is responsible to degenerate. The mother's sin against eugenics is visited on the generations that follow." (Childs, 150). Therefore, taking these symbols in mind, one can corporate that Yeats as a philosopher who was obsessed with the spiritual or philosophical vision of the life and death. For him, the study argues, life after death is permanent if compared to the temporal or physical existence .The dead can feel and suffer the pains because of their earlier earthy life. This fact of is reveals some of Yeats interest in searching of a new spiritual creed, perhaps this vision is best seen in his experimentations of the automatic script in which he asked questions to the spirits and he recorded their answer in documented sessions. Much of his philosophic views are summarized in a book entitled $A$ Vision $B$ in 1937. In This book he gives us an account of the afterlife. Yeats believed in the souls' ability to incarnate or discarnate themselves. To clarify more, he sees life in a form of a wheel, sequential transgression from one stage to another. The process is sequential and systematic, it shows the transformation of the soul after death as he called from wills to spirit, or in other words from the light of perception to the light of intellect. For Yeats, death is like awakening. There is a new life with its different forms and dimensions (Mann, 2012).

It seems worthwhile then to link the cultural analysis with eugenics to conceive Yeats' meaning clearly. In fact, Purgatory uncovers additional details about Yeats' interest in Eugenics at the end of his life, Yeats believed in Eugenics and indeed there are recurrent references by Yeats to the responsibility of the parents in selecting the right mate to avoid a degeneration of their children. In Modernism and Eugenics, Donald Childs comments on Yeats' perspective of Eugenics as:

The confident reference by Yeats... to these children as "fools" casts aspersions not so much upon the children as upon their parents: they have begotten unadvisedly. In the words of Purgatory, they have begot, and passed pollution on these misbegotten are the result of a bad marriage. (181)

However, we can widen the scope of the "biological" Eugenics to include history. Applying Eugenics on the history or as Vereen M. Bell calls "the Eugenic society", we can conclude that "what Yeats had said of his own temperament in relation to science was relevant to his sense of history as well: I am philosophical not scientific, which means much until I can make them a part of my experience"(Bell,76). Thus, if history is repeating itself, Childs argues, "we must be where the tendency to treat the first engagement with eugenics as farce...", he even suggests that "we must first attempt to repossess the discourse of eugenics- ostensibly a scientific discourse implicated in imperialist politics, the economics of overpopulation and depopulation" (20). But Yeats' perspective of eugenics is simply stated far away from the scientific complications, for Yeats, eugenics is a hopeless restatement of the supremacy of quality in the face of the conquest of capacity. (Culling ford, 1984, 230) Only at this point do we realize that Yeats asserted having a good "quality" of the Irish people rather than the "quantity", yet his hope of improving the future generation was unfortunately shattered after the bloody events of the civil war and the establishment of the Free State which changed the social order of the Irish society with the rise of the middle class Catholics and the fall of the Anglo-Irish Protestant Ascendancy. So, taking Purgatory in this analogy, Yeats' sense of pessimism is apparent due to the failure of his hopes of the postindependent Ireland.

Not only this pessimism indicated with the Irish issue; on the contrary, Yeats also regarded this change as a danger threatening the European civilization. Yeats' view of civilization is "almost at the end of its cycle, and the present time already filled with hints and portents of the new annunciation which will begin the cycle to come." (Brooks, 47) It is not strange then that Yeats previewed the end of Irish aristocratic class to which he belonged, Knowland states that Yeats regarded it as a "symptom of the degeneracy which he claimed was eroding the traditional sanctities of Irish and European civilization" (228).Consequently, in this light we can understand the Old Man's tragedy as an expression of Yeats' own pessimistic view of the social and the cultural degeneracy. The old Man justifies his killing of his son because he believed that if he had grown up, he would repeat the same mistake his father had done earlier in his youth when he married a woman better than him, and so, if this is done as Yeats expressed it, his children would "pass pollution on". (Yeats, Purgatory, 205-207) 
Donoghue attempted to interpret the Old Man's murder as a 'crime'. This marriage is a "crime against herself [the mother], a corruption of nature and of history. The boy is the degraded consequence of generation gone rotten. The Old Man who killed his father now kills his son in an endless cycle of retribution and remorse" (1986, 60). Though the Old Man's sacrifice of his son by killing him to have purgation for his mother's soul, yet his mother's ghost reappears which means that even the sacrifice of the son, the purgation didn't succeed. Thus, by ending the play in this way, we sense the irony because the "circle" of "horror" repeats itself without having an end.! Donoghue clarifies this "circular band of horror" as the son kills the father, the father kills the son and so on. This circular crisis still "failed to break the suffering spirit's bondage"(Donoghue, 61). Realizing this fact, the Old Man ends the play with a prayer to God:

O God

Release my mother's soul from its dream!

Mankind can do no more. Appease-

The misery of the living and the remorse of the dead.

(Yeats, Purgatory, 219-222)

The Old Man's cry symbolically includes all humanity suffering in the modern world with the increasing materialism. Ireland is symbolically presented as a ruined old house that though the Old Man sacrificed his son to rescue his home and his mother" Ireland", but he failed.

\section{Conclusion}

In purgatory, Yeats presented a negative view that predicted the near end of the European material civilization. Thus, if we regard Purgatory in this line of thought, the cultural message is clarified since Yeats warned the Irish people in particular, and the Europeans in general of the danger that threatened their civilization unless the spiritual and social orders are reestablished correctly. Having in his mind the Irish audience, Yeats sought to "cultivate" and educate the Irish minds so that they could choose the best choices for the future of Ireland by having in mind the hybrid reality which is still seen in the Irish society.

The idea of having Ireland governed by a cultural elite is the message presented in Purgatory. The study concluded that Yeats believed that this "elitism" is the solution that could take Ireland away from the material middle class values and thus, it will put Ireland in line with the noble spiritual values and culture. In other words, as the study proved, Yeats was disappointed for what he considered an intellectual degeneration of literature"; Yeats addressed the Irish public saying: except there is a revolution in the Irish people's mind, every class above the lowest must deteriorate, and so poorer men push up into the gaps, which would cause a great degeneration,

To sum up, in Purgatory, Yeats presented his own philosophical vision as he wanted the Irish audience "to realize the threats of what he professed as a degradation of the human existence, and a decrease in spiritual values of European civilization. The study concludes that Yeats is a nationalist, a dramatist and a philosopher as well. Yeats Purgatory expressed a far-sighted educational philosophy regarding the Irish identity. The cultural authority was existent in his works, besides his awareness of drama as a public art enabled him to present his vision of the Irish identity as "ethnic", pure and spiritual. He rejected the marginalization of the Protestant Ascendency in its both the spiritual and political dimensions. 


\section{REFERENCES}

Alison, J. (1999). Yeats's political Identities: Selected essays. Michigan: Michigan university Press.

Boyce, D. (1991). George. Nationalism in Ireland. London: Routledge, 1982.

Child, D. J. (2001). Modernism and Eugenics Woolf, Eliot, Yeats and The Culture of Degeneration. NJ, USA: Cambridge Univ. Press.

Bell, M. (2006). Vereen. Yeats and the Logic of Formalism. Columbia and London: University of Missouri press.

Burke, H. (2007). "Acting in the periphery the Irish theatre' 'in The Cambridge Companion to British Theatre1730-1830. (Eds.) Jane Moody and Daniel O 'Quinn. USA: CUP, pp219-232

Culling ford, E. (1984). Yeats, Ireland and Fascism. London: Macmillan.

Donoghue, D. (1986). We Irish: Essays on Irish Literature and Society. Brighton: The Harvester Press.

Eliot, T.S. "Yeats" in Yeats: A Collection of Critical Essays." (Ed.) Unterecker. USA: Prentice Hall, 1963, 54-63

Foster, R. (1999). " Protestant Magic: W. B. Yeats and the Spell of Irish History" in Yeats's political Identities: Selected essays. Alison, Jonathan (ED.). Michigan: Michigan University, Press.

Glock, W. G. and George A. (1966). (Eds.). Introduction to Literature.4th ed. New York: Holt, Rinehart and Winston, Inc.

Grene, N. (2000). Politics of Irish Drama: Plays in Context from Boucicault to Friel. Port Chester, NY, USA: Cambridge University Press.

Holdeman, D. (2006). The Cambridge Introduction to W.B. Yeats. United Kingdom: cup.

Howes, M. (1996). Yeats's Nations, Gender, Class and Irishness. Cambridge CUP.

Jeffares, N. (Ed.). (1980). William Butler Yeats: Selected Plays, Poems Criticism and Prose. Ed. London: Macmillan.

Kiberd, D. (1996). Inventing Ireland. London: Jonathan Cape.

Larrissy, E. (Ed). (1997). W.B. Yeats: A Critical Edition of The Major Works. New York: Oxford UP.

Neil Mann, N.et.al. (Eds.). (2012). W. B. Yeats's "A Vision": Explications and Contexts .Clemson University.

Maxwell, D. (1988). A Critical History of Modern Irish Drama. New York: Cambridge.

Michael A. (2010) .Michael. Yeats and European Drama. Cambridge: cup.

Said, E. (1992). "Yeats and Decolonization" in Nationalism, Colonialism and Literature. Minneapolis: Univ. of Minnesota Press, , 69-95.

Smyth, G. (1998) Decolonisation and Criticism: The Construction of Irish Literature. London: Pluto Press.

Torchiana, D. (1966). W.B. Yeats and Georgian Ireland. North-western U.P.: OUP.

Ure, P. (1969). Yeats The Play Wright. London: Rutledge \& Kegan Paul.

Vender, H. (1963). Yeats's Vision and the Later Plays. Cambridge: Mass. 